
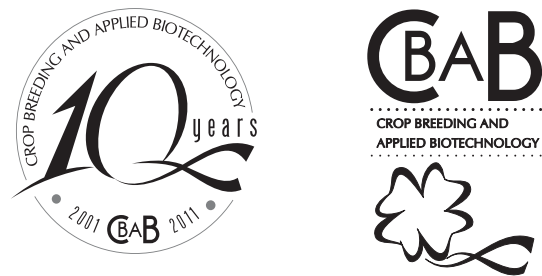

\title{
CD 120 - wheat cultivar, standard quality soft, for the Southern Region of Brazil
}

Volmir Sergio Marchioro ${ }^{1 *}$, Francisco de Assis Franco ${ }^{1}$, Tatiane Dalla Nora ${ }^{1}$, Edson Feliciano de Oliveira ${ }^{1}$, Ivan Schuster ${ }^{1}$, Adriel Evangelista $^{1}$, Renato da Rocha ${ }^{1}$ and Mateus Polo ${ }^{1}$

Received 27 January 2011

Accepted 18 July 2011

ABSTRACT - The cultivar CD 120, developed by the Cooperativa Central de Pesquisa Agricola (COODETEC) is suitable for cultivation in the VCU wheat-producing regions 1 and 2 of the states of Paraná, Santa Catarina and Rio Grande do Sul. It is tolerant to the major wheat diseases and pre-harvest germination and has soft wheat quality and a $6.5 \%$ higher grain yield (3.678 $\mathrm{kg}$ $\left.h a^{-1}\right)$ than the control.

Key words: breeding program, soft wheat, grain yield.

\section{INTRODUCTION}

The grain processing quality of certain wheat cultivars can raise the market value of harvested grain. The choice of an appropriate cultivar and cultural treatments may contribute substantially to obtain the desired classification of grain processing quality. The cultivar is one of the factors that determine the industrial suitability of wheat, which can be extra-strong, soft or bread-making quality. However, the interaction of the cultivar with the environment has a direct influence on the composition of the harvested grain, which may not always represent the full potential quality of the cultivar (Mandarino 1993).

Environmental variations often outweigh those due to the genotype and according to Mac Ritchie and Gupta (1993), environmental factors such as soil type and fertilization levels, in particular the nutrients nitrogen and sulfur, can affect the protein content and produce changes in the processing grain quality for.
Among the meteorological factors, temperature, rainfall and radiation have the greatest influence on the adaptation and grain processing quality of wheat. In this sense, the most efficient way to reduce risks for producers is to apply practices that minimize the impact of extreme weather fluctuations and maximize the effect of favorable weather conditions.

To meet these demands, the Cooperativa Central de Pesquisa Agrícola (COODETEC) is about to release another wheat cultivar, CD 120, on the market. The cultivar is tolerant to the major diseases, has a high grain yield potential and soft wheat quality.

\section{PEDIGREE AND IMPROVEMENT METHODS}

The cultivar CD 120 was obtained from the cross between the genotypes RUBI and CD105, conducted by COODETEC in 1998 in Palotina, Paraná. The $\mathrm{F}_{1}$ generation was advanced to $F_{2}$ in the same year in Cascavel by the mass method. By the same improvement

${ }^{1}$ Cooperativa Central de Pesquisa Agrícola (COODETEC), BR 467, km 98, C.P. 301, 85813-450, Cascavel, PR, Brasil. *E-mail: volmir@coodetec.com.br 
method, the $\mathrm{F}_{3}$ generation was obtained in 1999 in Cascavel. The $\mathrm{F}_{3}$ to $\mathrm{F}_{6}$ populations were bred by the pedigree method in the following years in Palotina. Lines that were uniform in the $\mathrm{F}_{6}$ generation were collected in bulk, giving rise to several sister lines that were tested for grain yield in the following years. The best of these lines originated cultivar CD 120 (pedigree CO15033-0T5P-4P-4P-0P).

\section{PERFORMANCE}

The lineage from which cultivar CD 120 was derived was tested in preliminary assays in 2004 and was included in the VCU (Value for Cultivation and Use) testing network in 2005, under the experimental name CD 0568. The VCU tests were conducted in the states of Rio Grande do Sul, Santa Catarina and Paraná, in the VCU wheat-producing regions 1 and 2 (Embrapa Trigo 2006), as shown in Table 1. harvest sprouting and lodging; lodging resistance is a particularly important factor of breeding for higher yields. The analysis of the grain processing quality of nine of the samples in different states indicated an average $111 \times 10^{-4}$ Joules for gluten strength (W). This result classifies CD 120 in the soft wheat cultivar group (Table 2), increasing the number of cultivars with white wheat quality, as in the case of CD 105 and CD 115, already available on the market (Marchioro et al. 2008). The flour quality of CD 120 is very characteristic for the intended use, with an average tenacity/extensibility ratio of 0.5 .

Field evaluations of plant collections (unrepeated parallel treatments to test genotypes for disease susceptibility) grown without disease control from 2004 to 2008 provided information on the main diseases affecting wheat. The severity of powdery mildew (Blumeria graminis f.sp. tritici) was average, characterizing the cultivar as

Table 1. Number of tests of value for cultivation and use (VCU) per state with the CD 120 cultivar in VCU wheat-producing regions 1 and 2

\begin{tabular}{|c|c|c|c|c|c|c|c|c|}
\hline \multirow{2}{*}{ State } & \multicolumn{4}{|c|}{ VCU Region 1} & \multicolumn{4}{|c|}{ VCU Region 2} \\
\hline & 2005 & 2006 & 2007 & 2008 & 2005 & 2006 & 2007 & 2008 \\
\hline Paraná & - & 4 & 4 & 4 & 3 & 4 & 3 & 3 \\
\hline Santa Catarina & 1 & - & 1 & 1 & 1 & - & 1 & 2 \\
\hline Rio Grande do Sul & 1 & 1 & 3 & 3 & 1 & 1 & 2 & 2 \\
\hline
\end{tabular}

The experiment was arranged in a randomized block design with three replications in plots consisting of six $5 \mathrm{~m}$-long rows, spaced $0.20 \mathrm{~m}$ between rows, with mechanical sowing. Fertilization and disease and pest control were performed according to the technical recommendations (Reunião 2011). Prior to sowing, the seeds were treated with triadimenol + imidacloprid. Among others, the following characteristics were assessed: grain yield, days from emergence to silking, days from emergence to maturity, plant height, lodging, hectoliter weight, 1000 grain weight, and gluten strength.

For these samples, foliar diseases were not controlled to evaluate the severity of diseases such as leaf rust, leaf spots, powdery mildew, head blight and wheat mosaic virus (Reis and Casa 2007). These collections were grown at representative locations of the wheat-producing regions, together with CD 120 and control cultivars.

Table 2 shows the average grain yield in the VCU wheat-producing regions 1 and 2 of the different states of the southern region of Brazil. Results show that the yield of CD 120 was 6 and $7 \%$ higher than the average of the two best controls, respectively, in the regions 1 and 2 . These percentages show the yield potential of this cultivar in the Central South of Paraná, Santa Catarina and Rio Grande do Sul.

In view of the performance of the cultivar, CD 120 was indicated for planting in the above-mentioned regions, i.e., the states of Paraná, Santa Catarina and Rio Grande do Sul. The variety was registered by the national plant variety protection service, of the Brazilian ministry of agriculture.

\section{OTHER TRAITS}

The average plant height of CD 120 is $85 \mathrm{~cm}$ (from 65 to $104 \mathrm{~cm}$ ). The cycle, classified as medium, lasts 72 days from emergence to silking (from 51 to 92 days) and 124 days from emergence to maturity (from 102 to 145 days). These characteristics may vary, according to the weather conditions, sowing date and soil type.

The ears of CD 120 are fusiform, in an intermediate position. The cultivar is moderately resistant to pre- 
CD 120 - wheat cultivar, standard quality soft, for the Southern Region of Brazil

Table 2. Average grain yield $\left(\mathrm{kg} \mathrm{ha}^{-1}\right)$ of cultivar $\mathrm{CD} 120$ and of the two best controls in the VCU wheat-producing regions 1 and 2

\begin{tabular}{lccccccc}
\hline Region & Cultivar & $\mathbf{2 0 0 5}$ & $\mathbf{2 0 0 6}$ & $\mathbf{2 0 0 7}$ & $\mathbf{2 0 0 8}$ & Mean & \% \\
\hline \multirow{2}{*}{ VCU 1 } & CD 120 & 3561 & 3697 & 3716 & 4475 & $\mathbf{3 8 6 2}$ & $\mathbf{1 0 6}$ \\
& Mean T & 3424 & 3482 & 3561 & 4139 & $\mathbf{3 6 5 1}$ & $\mathbf{1 0 0}$ \\
\cline { 2 - 7 } VCU 2 & CD 120 & 2819 & 3908 & 3350 & 3898 & $\mathbf{3 4 9 4}$ & $\mathbf{1 0 7}$ \\
& Mean T & 2597 & 3712 & 3160 & 3622 & $\mathbf{3 2 7 5}$ & $\mathbf{1 0 0}$ \\
\hline
\end{tabular}

* the two best controls used in the comparison (Mean T) were ONIX and SAFIRA in 2005; FUNDACEP NOVA ERA and ONIX in 2006, FUNDACEP NOVA ERA and SAFIRA in 2007; and, FUNDACEP NOVA ERA and ONIX in 2008.

Table 3. Means of days from emergence to silking (ES), days from emergence to maturity (EM), plant height (PH), lodging (L), weight $(\mathrm{HW})$, gluten strength $(\mathrm{W})$, tenacity/extensibility ratio (P/L), leaf rust (LR), leaf spot (LS), powdery mildew (PM), blight (BL) and wheat mosaic virus (MV) cultivar CD 120 and ONIX control

\begin{tabular}{|c|c|c|c|c|c|c|c|c|c|c|c|c|}
\hline Cultivar & $\frac{\mathbf{E S}}{\text { (days) }}$ & $\frac{\mathbf{E M}}{\text { (days) }}$ & $\frac{\mathbf{P H}}{(\mathrm{cm})}$ & $\frac{\mathbf{L}}{(\%)}$ & $\frac{\mathbf{H W}}{\left(\mathrm{kg} \mathrm{hl}^{-1}\right)}$ & $\frac{\mathbf{W}}{\left(10^{-4} \text { Joule }\right)}$ & $\frac{\mathbf{P} / \mathbf{L}}{\text { (ratio) }}$ & $\frac{\text { LR }}{(\%)}$ & $\frac{\mathbf{L S}}{\text { (grade 0-9) }}$ & $\frac{\mathbf{P M}}{\text { (grade 0-9) }}$ & $\frac{\text { BL }}{\text { (grade 0-9) }}$ & $\frac{\text { MV }}{\text { (grade 0-9) }}$ \\
\hline & 70 & 121 & 84 & 11 & 77 & 111 & 0.5 & 30 & 3.8 & 2.9 & 3.8 & 6.3 \\
\hline ONIX & 72 & 125 & 84 & 5 & 77 & 248 & 1.5 & 57 & 3.8 & 1.8 & 3.0 & 2.0 \\
\hline
\end{tabular}

moderately resistant. For head blight (Fusarium graminearun), CD 120 was classified as moderately susceptible, within a same line of cultivars already released by COODETEC (Marchioro et al. 2004). For leaf blotch (Bipolaris sorokiniana) and glume blotch (Septoria tritici and Stagonospora nodorum), average severity levels of leaf blotch and glume blotch were observed, classifying CD 120 as moderately susceptible. The severity of the evaluations of leaf rust (Puccinia recondita f.sp. tritici) was average under field conditions, indicating moderate susceptibility. The severity of wheat mosaic virus was high, indicating moderate susceptibility of CD 120 (Table 2).

\section{SEED MAINTENANCE AND DISTRIBUTION}

The COODETEC (BR 467, km 98, CP 301, 85.813-450, Cascavel, PR, Brazil, licenses seed companies under contract (law No. 9456/97) that multiply and sell seeds of protected cultivars.

\section{120 - cultivar de trigo, padrão de qualidade macio, para a região sudeste do Brasil}

RESUMO - O cultivar CD 120, desenvolvido pela Cooperativa Central de Pesquisa Agrícola (COODETEC) é recomendado para cultivo nos VCUs para as regiões 1 e 2 do Paraná, Santa Catarina e Rio Grande do Sul. É tolerante às principais doenças, à germinação pré-colheita, tem qualidade de trigo macio e é $6.5 \%$ mais produtivo $\left(3.678 \mathrm{~kg} \mathrm{ha}^{-1}\right)$ que a testemunha.

Palavras-chave: programa de melhoramento, trigo macio, produção de grãos.

\section{REFERENCES}

CD 115: Soft wheat cultivar for colder regions. Crop Breeding and Applied Biotechnology 8: 255-258.

Mandarino JMG (1993) Aspectos Importantes para a qualidade do Trigo. Embrapa Soja, Londrina, 32p. (Documentos, 60).

Marchioro VS, Franco AF, Dalla Nora T, Schuster I, Oliveira EF and Sobrinho AA (2004) CD 110 - Wheat cultivar. Crop Breeding and Applied Biotechnology 4: 360-361.
Marchioro VS, Franco AF, Dalla Nora T and Oliveira EF (2008) Mac Ritchie F and Gupta RB (1993) CD 116: Functionalitycomposition relationships of wheat-flour as a result of variation in sulphur availability. Australian Journal of Agricultural Research 44: 1767-1774.

Reis EM and Casa RT (2007) Doenças dos cereais de inverno. Diagnose, epidemiologia e controle. Graphel, Lages, 176p. 
VS Marchioro et al.

Reunião da Comissão Brasileira de Pesquisa de Trigo e Triticale (2011) Informações técnicas para trigo e triticale: safra 2011. $4^{\text {th }}$, Coodetec, Cascavel, 170p.Embrapa Trigo (2006)

Regiões de adaptação para trigo no Brasil. Available at http:// www.cnpt.embrapa.br/biblio/ci/p_ci20.htm>. Accessed on 5 Nov., 2010. 